\title{
Language policy implementation in South Africa: How Kempton Park's great expectations are dashed in Tshwane ${ }^{1}$
}

\author{
Anne-Marie Beukes \\ University of Johannesburg, PO Box 524, Auckland Park, 2004 \\ ambeukes@uj.ac.za
}

\section{Introduction}

Almost two decades ago, on 2 February 1990, the waiting world learnt that the ban on the previously exiled African National Congress (ANC) was lifted and that Nelson Mandela would be released from prison within a matter of days. On that historic day when then State President FW de Klerk made his dramatic announcement in Parliament, I was one of the participants in a public colloquium, "Planning for the future: Language in South Africa", held at the University of the Witwatersrand (Wits). The colloquium was part of an International Symposium on Sociolinguistics in Africa of which the main objective was "to re-examine the complex linguistic situation in Southern Africa in the light of changing socio-political conditions" (Herbert 1992: ix).

On that day, when the watershed between apartheid South Africa and the promise of a future democratic dispensation was captured in De Klerk's dramatic announcement, the renowned American linguist, Carol Eastman, introduced her colloquium at the Wits Symposium with the following categorical statement: "The African National Congress (ANC) has identified language as an area in need of planning for post-apartheid South Africa" (Eastman 1992: 95). 
Following the high expectations in the run-up to the "new South Africa" that a free and democratic political system would bring about transformation, South Africans were witness to a flurry of policies and interventions in most sectors of society. These policies were generated in aid of the government's reconstruction and development project, aimed at effecting radical social redress, securing economic development and building a united nation. Government's point of reference was the Reconstruction and Development Programme (RDP), with its "single vision of creating a people-centred society", with which it set out, in the words of Nelson Mandela in Parliament in May 1994, to -

help establish a social order in which the freedom of the individual will truly mean the freedom of the individual ... to create a people-centered society of liberty binds us to the pursuit of the goals of freedom from want, freedom from hunger, freedom from deprivation, freedom from ignorance, freedom from suppression and freedom from fear. These freedoms are fundamental to the guarantee of human dignity. They will therefore constitute part of the centrepiece of what this government will seek to achieve, the focal point on which our attention will be continuously focused. The things we have said constitute the true meaning, the justification and the purpose of the Reconstruction and Development Programme, without which it would lose all legitimacy.

Although language was not included in the RDP framework, an omission that could arguably be construed as an early indication that language would not clearly feature as part of the "centrepiece", a bold start was made with several ground-breaking language planning activities, among which the Language Plan Task Group (Langtag) process and the establishment of the Pan South African Language Board (PanSALB) within the first two years of democracy.

In just more than a decade Government made progress in effecting a radical break with the past and improving the social well-being of those citizens who were previously disadvantaged. For example, some 780 new laws were passed to create a platform for reconstructing and developing the country, housing was provided for more than six million 
people, expenditure on fighting HIV/Aids increased ten-fold, households with access to electricity increased by $40 \%$ and access to clean water by $25 \%$ (Sunday Independent 2004).

As regards language diversity issues, the first 10 years of democracy also produced several policy processes. The outcomes of these processes are captured in, among other things, South Africa's only piece of language legislation, the Pan South African Language Board Act (Act No. 59 of 1995), and the National Language Policy Framework (2003). ${ }^{2}$ In addition, several other language policy documents have seen the light (cf. Du Plessis 2006: 43-4):

1. the Language in Education Policy (Government Notice No. 383, Vol. 17997, in terms of section 3(4)(m) of the National Education Policy Act, 1996;

2. Norms and Standards on language policy (Government Notice No. 383, Vol. 17997, in terms of section 6(1) of the South African Schools Act, 1996), which regulates language policy in schools; and

3. the Language Policy for Higher Education (2002), which regulates language dispensations in higher education institutions.

Notwithstanding the above list of enabling legislation and language policies it seems as if disillusionment has set in. In an editorial to mark the celebration of a decade of democracy in South Africa the Sunday Times (25 April 2004) laments the fate of the country's indigenous languages:

We find that our 10-year-old democracy has been the greatest enemy of indigenous languages. All the lofty pronouncements made in the early days of transition seem to have been thrown out of the window and the authorities have paid token attention to the issue. The work of government is conducted virtually entirely in English and the language of our culturally diverse Parliament is almost exclusively English. Many senior politicians stay away from African language radio stations, presumably because they perceive those audiences as not sophisticated enough. .... Universities are battling to keep African language departments open as student numbers dwindle ... book publishing in indigenous languages is on its deathbed, and ... the use of these languages among native speakers is becoming unfashionable. 
It is common knowledge that language policy implementation is a matter of concern for language stakeholders and experts alike. It seems as if government lacks a commitment to its own policy, the National Language Policy Framework (NLPF), approved by Cabinet in 2003 and that language matters have been relegated to the back seat of the transformation agenda. Almost two decades after the watershed Wits conference on language planning for a future South Africa, I would like to reflect on the road travelled from the constitutional settlement reached by the multi-party negotiators in Kempton Park in 1993 to the present. This reflection will focus on Langtag as an "exemplary" policy process and on the range of perspectives on what may be described as the current "retrogressive" situation of widespread policy failures. Such a reflection must of necessity address the new challenges that the title of this paper evokes, i.e. what are the new challenges that government now faces? Language policy and planning, after all, is contextually determined and its implementation should therefore be evaluated by taking into account relevant social, cultural and economic interests (Pennycook 2000; Ricento 2000).

\section{Methodological choice: an insider's perspective}

In reflecting on post-apartheid language policy processes I have to declare my insider's position up front. ${ }^{3}$ At the end of 1993, at the time when the Constitution's language clauses were being finalised by the negotiators at Kempton Park, I left academia to join the government's State Language Services in Pretoria to assist with setting up a new subdirectorate, i.e. the Language Planning Section. Since its establishment in 1930 the State Language Services, the government of the day's language office, rendered a national translation and editing service to government structures, but had never engaged in overt language planning activities. With the advent of the new multilingual dispensation it was expected that the State Language Services would require a section dedicated to language policy and planning. Over the next few years of "the Transition" a flurry of language policy initiatives - as elsewhere - saw the light. Thus the Language Planning Section was directly involved in the conceptualisation and management of all the major language policy initiatives, concomitant public consultation processes, as well as the protracted legislative process on PanSALB. ${ }^{4}$ 
The unique and complex political circumstances that characterised language policy initiatives during the era of transition are evident from the situation regarding another historic language conference in which I participated, namely the Languages for All Conference, held a month after the new South Africa came into being. The preparations for the Conference commenced early in 1994 soon after the interim Constitution was finalised in December 1993. The fact that the ANC's Arts and Culture Desk, headed by Wally Serote, agreed to be a member of the Organising Committee together with the State Language Services of the then Department of National Education, as well as language bodies and individual sociolinguists even before the ANC officially came into power on 27 April 1994, was particularly significant. The Conference, held in Pretoria on 27 and 28 May 1994, was the new democracy's very first representative consultative language conference. Some 400 participants broadly representative of major language stakeholders attended the Conference to debate two important issues, namely (i) the process of drafting the legislation on the Pan South African Language Board as envisaged in the language provision of the interim Constitution, and (ii) consultation on the new institutional structures that would be required to support the new multilingual dispensation. The importance that language stakeholders and experts attributed to this event is evident in Webb's (2002: 289) view that the Conference is "arguably the major event in the history of language planning in South Africa".

My reflection on language policy processes is thus based on my insider's knowledge and experience of language matters and events since the early nineties. The so-called insider's perspective in terms of which research is conducted in the humanities acknowledges that bias may indeed be present, but that researchers' interests and insights contribute to arriving at a "dynamic dialogue" (Moore 2000: 39). Grobbelaar (1991: 24) argues that -

all research is done by real people with genuine interests to pursue and hatchets to grind and ... therefore human interests and values are always, (albeit most often implicitly), incorporated not only into researchers' analyses but, moreover, into their very choice of methods.

However, the insider's perspective does not exclude probing one's understanding and interpretation of events (Moore 2000). 
The scope of this paper does not allow for a comprehensive analysis of the entire series of policy initiatives of the past two decades. I have thus chosen to direct my gaze to what I view as the watershed language planning event in post-apartheid South Africa, namely the setting up in 1995 of the Language Plan Task Group (Langtag) by Ben Ngubane, the Minister responsible for language matters at the time. My reflection on Langtag is approached as a case study. The possibility of looking back and reflecting on events based on first-hand experience and knowledge of the process(es) is an important methodological advantage associated with case studies. In addition, the analysis of official documents and a study of relevant literature may potentially produce comprehensive and nuanced research results. It is hoped that the dynamic "dialogue" that is the result of the simultaneous utilisation of the insider's close knowledge of the Langtag process and the reflective analysis of the researcher will lead to new perspectives on and insight into the language planning initiatives of the early postapartheid era.

\section{Langtag and bottom-up language planning}

In addition to the question of who the intended beneficiaries of policies are and what "goods" they are supposed to receive, the question of who initiates and executes these activities is also central to policy processes. Language planning activities traditionally fit the top-down model of "people with power and authority who make language related decisions for groups, often with little or no consultation with the ultimate learners and users" (Kaplan and Baldauf 1997: 196). It is exactly this feature of the Langtag process that represents a departure from traditional language planning practices.

Langtag chairperson, Neville Alexander, argued that the mix of top-down with bottom-up planning was one of the distinguishing characteristics of this process: "Because of the peculiarities of the political transition in South Africa, it has unique features even as an exercise in applied linguistics, especially in its delicate balance between State and non-State elements of policy determination" (Department of Arts, Culture, Science and Technology 1996: 11). Alexander distinguished himself as one of the keen proponents of the so-called bottom-up approach to language planning since the 1980s. At the February 1990 Wits Symposium he warned against planning according to the canonical model because of it being "too much government-orientated" (Alexander 1992: 143). He argued in favour of a more 
flexible approach in terms of which non-governmental organisations such as language associations, community organisations and other language stakeholders were involved in order to counteract centralised control of language planning activities. Alexander based his argument on the so-called "right to propose principle (which) is the essence of any democratic system" (Alexander 1992: 46), the restriction of which right would be an act of oppression and dehumanisation.

In retrospect, Langtag's "inclusive" approach represented a fundamental break with apartheid language planning practices and hence contributed to the widely acknowledged status of the Final Langtag Report, notwithstanding the fact that government never adopted it as an official position paper. Heugh's (2002: 179) view that the Report is "a significant document which presents the culmination of the widest and most consultative national process on language policy and planning ever conducted in South Africa" is representative of the high esteem in which the Langtag process was held.

\subsection{The establishment and development of the Langtag policy process}

Langtag was established in the rosy hase of the post-1994 context when a general "feel-good" climate was evident across the country. A political miracle for all the world to see had just been effected in Kempton Park during the constitutional negotiations and, in an unprecedented spirit of reconciliation, the country was subsequently governed by a Government of National Unity led by Nelson Mandela. The people of South Africa appeared to be committed to honouring their highly acclaimed, progressive Constitution.

The power of the executive arm of government in language matters was transferred to the newly established Department of Arts, Culture, Science and Technology (DACST), headed by the medical doctor turned IFP politician, Ben Ngubane, with the controversial ANC activist, Winnie Mandela, as his deputy-minister. A young scientist from the ANC's Science and Technology desk, Roger Jardine, was appointed Director-General of a seemingly unwieldy government department. Notwithstanding the lack of expertise of the political and executive leadership as far as language matters were concerned, Ngubane proved to be fairly amenable to initiating the language policy development processes (cf. the Languages for All Conference in 1994 and Langtag in 1995). It soon became clear that the seasoned IFP minister and the inexperienced ANC director-general managed against all odds to establish a good working 
relationship. In fact, Ngubane's harmonious relationship with the ANC led to dissatisfaction within his party and he was "redeployed" to KwaZulu-Natal as premier of the province soon after the Langtag process was completed. Yet another IFP politician, Lionel Mtshali, was subsequently appointed to this portfolio, which soon resulted in DACST becoming known as a dumping ground for IFP politicians. Its status as government's Cinderella department, because of its awkward configuration of focus areas and the choice and rotation of IFP politicians to head the department, served as confirmation that language matters were relegated to government's backseat.

This situation resulted in civil society losing confidence in the ability of DACST to deal adequately with the complex language question. After the good progress made in preparing the way for the establishment of PanSALB, concern was raised about government's political commitment to managing the legislative process required for the establishment of the Board. Non-governmental organisations such as the National Language Project (NLP) and the Project for the Study of Alternative Education in South Africa (Praesa) under the leadership of Neville Alexander and his colleague, Kathleen Heugh, who were both actively involved in bottom-up language planning activities prior to 1994, raised their concern in parliamentary circles. They campaigned for the relocation of the executive management on language matters from the "dysfunctional" DACST to the "successful" Department of Constitutional Development.

After mediation by Neil Barnard, then Director-General of Constitutional Development, a joint workshop was held in February 1995 with his department and DACST in collaboration with Praesa. The participants, who included parliamentarians, representatives from nongovernmental organisations (NGOs) and language associations, agreed that -

1. the management of language matters would remain within the jurisdiction of the DACST;

2. the establishment of a Language Board was a high priority;

3. "the implementation of a national language plan should become an immediate objective of government"; and 
4. $\quad$ "a non-governmental advisory group should be established to put forth the necessary recommendations needed for the implementation of a national language plan".

(DACST 1995: 2-3)

Through a process of bottom-up pressure on DACST a climate was created that "compelled" the Minister to honour his department's language policy and planning brief. In a letter dated 10 October 1995 Ngubane subsequently invited seven prominent linguists "to collectively devise a coherent national language plan which would encompass all state structures and civil society" (DACST 1996a: 7). The Language Plan Task Group (Langtag) was thus established. The following experts from language associations, statutory bodies, NGOs and universities were appointed to the Langtag Main Committee:

1. Neville Alexander (language activist involved in NGOs such as the NLP and Praesa)

2. Quedisizi Buthelezi (Department of Linguistics at the University of the Witwatersrand and former member of ANC's Arts and Culture Desk)

3. Khethiwe Marais (owner of the translation agency Afrophone and former member of ANC's Arts and Culture Desk)

4. Themba Msimang (Head of the Department of African Languages at Unisa)

5. AC Nkabinde (Editor in Chief of the Zulu Dictionary Project at the University of Zululand and chairperson of the SABC Board's Language Committee)

6. Gerard Schuring (Head of the Unit for African Languages of the Human Sciences Research Council)

7. Vic Webb (Department of Afrikaans and Linguistics at the University of Pretoria, Chairperson of the Linguistics Society of Southern Africa and Director of LiCCA, an international language planning research programme)

At Langtag's first meeting on 9 November 1995, where Neville Alexander was elected chairperson, Ngubane stipulated that a language plan for South Africa would have to be a statement of the country's language-related needs and priorities and should set out to achieve the following objectives: 
1. All South Africans should have access to all spheres of South African society by developing and maintaining a level of spoken and written language which is appropriate for a range of contexts in the official language(s) of their choice.

2. All South Africans should have access to the learning of languages other than their mother tongue.

3. The African languages, which have been disadvantaged by the linguicist policies of the past, should be developed and maintained.

4. Equitable and widespread language services should be established.

Langtag's brief was to involve linguists and language stakeholders in a process of consultation to address specific language issues with a view to advising the Minister on a coherent national language plan. A Langtag subcommittee, each chaired by a member of the Main Committee, was appointed through a public call for nominations to investigate the following issues:

1. Language equity

2. Language development

3. Language in education

4. Literacy

5. Language in the Public Service

6. So-called heritage languages, ${ }^{5}$ South African Sign Language, and Alternative and Augmentative Communication (AAC)

7. Equitable and widespread language services

8. Language as an economic resource

Ngubane requested that a report be submitted to him within a period of eight months in view of the urgency of giving concrete effect to the language provisions of the Constitution:

... the alternative of conducting a lengthy process would simply be too costly both in terms of financial and human resources - for a country which, two decades after Soweto 1976, still had no coherent language plan. ... we had to pull out all stops to ensure that multilingualism becomes a reality in this country. 
Langtag's commitment to bottom-up language planning was evident from its extensive committee system for conducting research and consultation. Seven subcommittees and one study group comprising a total of 35 language experts and stakeholders were involved over a six-month period in a process of consultation through workshops and seminars on a variety of policy needs and priorities. After consulting with language stakeholders, experts and interested persons and parties, each subcommittee submitted a comprehensive report on its consultation processes and research findings to the Main Committee. A draft Langtag Report was subsequently compiled and distributed to stakeholders and interested parties.

In order to consult as widely as possible the draft Report was debated at the Langtag Consultative Conference convened by the Minister on 29 June 1996 in Pretoria. Some 500 participants broadly representative of language stakeholder groups and language experts took part in this conference (The Star 1996). At the Conference a public call was made to all language stakeholders and interested persons to make submissions on the scope and substance of the Langtag Committee's research and its recommendations regarding a national language plan prior to finalising its report to the Minister. After considering all submissions the Final Langtag Report was compiled and presented to Ngubane on 8 August 1996 for consideration and action.

The Langtag Report can be divided into three parts, namely (i) an exposition of the Committee's work and an overview of the process and recommendations, (ii) an extensive report on the outcomes of the research and consultation process managed by the Main Committee, and (iii) two sets of recommendations (short term and long term) to the Minister to be used as a possible framework for the envisaged language plan.

The Langtag Report pointed to a general disregard for the principle of language equity from Parliament to all three levels of government. The Report also pointed to a lack of commitment in the Public Service to implementing a policy of multilingualism and to a discernable trend towards monolingualism among the political, business and educational leadership (DACST 1996a: 156). In addition, the Report addressed the ongoing legitimisation of monolingualism and found that arguments regarding the superior position of English as an international language and the access that the language offers through its "technological advances" and 
"trade benefits", as well as the perceived "cost advantages" of using a language "which all South Africans understand", were popular (DACST 1996a: 156).

\subsection{Was Langtag indeed a watershed?}

Upon receiving the Final Langtag Report Ngubane confirmed his commitment to implementing the Constitution's provisions on language. According to him the Langtag Report would serve as "a road map" for his Department "on how to make the constitution more meaningful" (Cape Times 1996). Moreover, the Minister was of the opinion that the Langtag Report was a watershed in the management of language matters in South Africa and that in future "this process would rank as one of the first serious attempts to grapple with the issue of managing South Africa's linguistic diversity in a positive manner" (Ngubane 1996). It is probably not too far-fetched to interpret these statements by the Minister responsible for language matters as an indication of the government's commitment to giving concrete effect to the recommendations of its Task Group.

Ngubane was redeployed to KwaZulu-Natal subsequent to the Langtag process, but upon his return to DACST three years later a protracted consultative process on his department's draft language policy began, based on Langtag's recommendations. Ngubane honoured his commitment to finalising a language policy after Langtag by appointing a small Language Policy Advisory Group in 1999, chaired once again by Neville Alexander. The Minister's brief to the Panel was to develop a draft language policy based on the Langtag recommendations for his consideration. This time round further consultation with government departments and Cabinet took place. Yet again a major consultative forum of language stakeholders was convened in 2000, at which occasion the first draft of the Language Policy and Plan was revised. This draft, together with the SA Languages Draft Bill, was prepared by the Advisory Panel in a remarkably short time.

The National Language Policy Framework (NLPF) was finally approved by Cabinet in 2003. The NLPF was devised as a package that would comprise a policy statement, an implementation plan, the South African Languages Act and the South African Language Practitioners' Council Act (DAC 2003a: 5). 
In the South African context Langtag does indeed represent a watershed. Although government took the initiative, the Langtag process was supported by mobilising language stakeholders across the board through systematic consultation by language experts in collaboration with government's executive arm in language matters (cf. Alexander's reference to a "delicate balance between State and non-State elements" as one of the important merits of the Langtag process (DACST 1996a: 11)). Langtag may therefore be viewed as representative of the highly acclaimed bottom-up approach and in that sense it signals a watershed in the management of linguistic diversity in South Africa.

\subsection{Why Langtag had only a moderate impact}

Now, just more than a decade after Langtag had successfully completed its mandate, it has become clear that, notwithstanding its meritorious bottom-up approach, very little attention has been paid to its recommendations in these past years. In fact, language planners have pointed to significant gaps between language policy and implementation, a situation that has more often than not been attributed to government's ineffective management of language matters (cf. Alexander 2000, 2002; Kamwangamalu 2000; Moodley 2000; Heugh 2003; Carstens 2006; Webb 2006) and the inadequate congruence between government's language policy statement and real language practice (cf. Verhoef 1998; Du Plessis 2006).

Even South Africa's President, Thabo Mbeki (2007), in his weekly letter on the ANC's website, ANC Today, recently turned his gaze toward language matters:

Quite correctly, many in our country have expressed concern about the place of the African languages in our society. This relates to such important matters as mother-tongue instruction in our schools, the study of African languages at the school and university levels, the publication of books and magazines in the African languages, the further development of these languages for use as media of instruction at higher levels of education, multilingualism, the use of indigenous languages in our state institutions, in the public discourse and public communication, and so on.

Mbeki's list of language issues echoes many of the findings reported in the Langtag Report a decade ago. In fact, each one of these issues featured prominently in the Report. 
Upon presenting the Final Langtag Report to the Minister, the Langtag chairperson, Neville Alexander, expressed the opinion that the process had unique features as an exercise in applied linguistics:

The creation of LANGTAG and the process by which it arrived at this final Report are on the surface quite normal and even mundane events in a society where every question and every attempt at transformation is obviously urgent. However, viewed from the perspective of language planning as a discipline within the field of applied linguistics and as a conscious practice, the LANGTAG process, short as it has been, is indeed one of the more significant developments in the second half of the $20^{\text {th }}$ century.

(DACST 1996a: 11)

However, against the backdrop of contemporary views on language policy and planning in South Africa I would like to argue that this supposedly exemplary language planning exercise does require re-evaluation. In retrospect it is important to bear the following in mind:

1. Langtag was established immediately after the dawn of the new democratic dispensation during the halcyon days of "the Transition" (April 1994 to May 1996) when South Africa was governed by a Government of National Unity headed by Nelson Mandela. His cabinet was made up of the majority party, the ANC, and minority parties such as the National Party (NP) and the Inkatha Freedom Party (IFP) and also boasted a number of women.

2. The constitutional negotiations at Kempton Park and the finalisation of the language clause in the interim Constitution in November 1993 contributed to a favourable political climate two years later when Langtag was conceptualised by government as an exercise in bottom-up language planning.

3. Langtag executed its mandate in the period between the interim Constitution of 1993 (Act No. 200 of 1993) and the adoption of the final Constitution in May 1996: the Langtag Main Committee was appointed in December 1995, the consultative Langtag Conference was convened in June 1996 and the Final Langtag Report was submitted to government in August 1996. 
4. Thorny constitutional issues, of which the "language question" was one, were finalised only at the eleventh hour during the negotiations at the Convention for a Democratic South Africa (Codesa) in Kempton Park in November 1993. Issues such as the affirmation of the indigenous languages, the official status of Afrikaans, those rights pertaining to languages that were applicable in the previous dispensation, and the right to mother-tongue education were some of the major concerns that required careful, unhurried deliberation.

\subsection{Langtag's limitations}

The resolution regarding the language question was one of the "sufficient give and take and reasonable compromises" that Codesa managed to pull off, according to former State President, FW de Klerk (De Klerk 1998: 287). The decision to enshrine official status for nine African languages - in addition to English and Afrikaans - in the Constitution was a political compromise because it would not have been feasible to retain the status quo of the apartheid regime that restricted official status to English and Afrikaans only. The ANC's supporters would most probably have accepted the option of English as sole official language, since it was the de facto lingua franca of the struggle era; however, this option would have been rejected by the (white) Afrikaans speech community. ${ }^{6}$

The sociopolitical context, therefore, required an acknowledgement of the value of the African languages and hence a revival of their status and use in order to facilitate their affirmation. However, it is important to concede that the demarcation of these languages according to the official status afforded to them as markers of ethnic identity in apartheid's separate homelands and independent states was the norm used by the Kempton Park negotiators. Du Plessis (2006), in a important contribution to the debate on policy implementation challenges, points to the controversial nature of this particular configuration of African language varieties because of its lack of congruity vis-à-vis the sociolinguistic reality of language use in South Africa.

The 11-language compromise arrived at during the final hours of negotiations late in November 1993 (De Klerk 1998: 287) was viewed by the constitutional negotiators as a "route ... meant to restore the dignity of South Africans whose languages had been degraded by the apartheid system" (Sunday Times 2004), but did not altogether meet with general 
approval. In fact, the constitutional affirmation of multilingualism was ridiculed - in particular in the English-dominated media. There were even indications at grassroots level that people were resigned to the idea that the use of 11 languages at all levels of society would not be feasible (cf. Verhoef 1998: 36).

The ANC's proposals regarding the issue of official language status at Codesa were uncritically based on the linguistic autonomy that was afforded to African language varieties during the colonial and apartheid eras. In addition to enshrining official status for nine African languages, section 3 of the interim Constitution provided for the non-diminution of rights and the extension of the earlier, limited status of African languages to national official status. Hence, the official recognition of objective differences between African languages and their varieties did not adequately address the social value that the speakers of these varieties ascribe to their languages (cf. Herbert 1992).

Looking back, it is clear that this important issue was not adequately addressed by the Langtag process. In fact, tension regarding this matter surfaced at a workshop held by the subcommittee on Language Development where the future of the apartheid language boards and the harmonisation of languages and varieties were discussed (Langtag 1996). The heated debate that ensued and the fierce opposition expressed against language harmonisation at the workshop resulted in the subcommittee promptly abandoning any further discussion of the issue. Other than publishing the proceedings of the workshop "in the interest of continuing the debate" (DACST 1996b: Preface), the language autonomy issue as far as the African languages were concerned was sidestepped in the Langtag Report (cf. DACST 1996a: Chapter 2 on language development). The Report concluded that the unification or harmonisation of African languages "does not seem to enjoy grassroots support" and that "(1)ack of understanding of what is involved in this type of language development seems to be one important reason for this lack of grassroots enthusiasm" (DACST 1996a: 77).

It is furthermore important to bear in mind that the inclusive spirit of the language clause in section 3 of the interim Constitution served as a framework for the Langtag subcommittee's research and concomitant recommendations. An important point of criticism against the outcome of the Langtag process and the way in which it shaped the Final Report must be directed at the Langtag leadership and their failure to give concrete effect to the Minister's 
brief. Instead of boldly "translating" the input from the consultation process in a clearly defined language policy proposal as requested by the Minister (cf. his brief to the Main Committee "to join hands with us (the Ministry) to collectively devise a coherent national language plan" (DACST 1996a: 7)), the Langtag Main Committee delineated its mandate as a mere needs-and-priorities analysis to be used by the Ministry as a "guideline" for policy development. The Langtag Main Committee's reinterpretation and toning down of the Minister's brief arguably resulted in a missed opportunity.

\section{Language policy development in the new democratic dispensation}

However, policy processes in transitional societies are especially prone to producing "gaps" and "disjunctions" between policy and implementation in "the pursuit of heavily contested, ideologically loaded, transformation goals" (Pretorius 2003: 6). In conjunction with Pressman and Wildavsky's (1973: xiv) working definition, I use the notion "policy" as "a hypothesis containing initial conditions and predicted consequences". In order to determine possible gaps in implementation, "initial conditions" (policy goals) should be scrutinised with a view to assessing whether and how "predicted consequences" (implementation) have been realised.

In this regard Pretorius (2003: 9) offers a useful distinction between two types of "predicted consequences". The first type, which is "commonly associated with political ideologies", comprises value statements that more often than not describe "desired consequences" and connote quality such as captured in the NLPF: equity, redress, promotion, commitment, enhance. However, the very elusive nature of such value-laden terms "could itself be a source of policy implementation gaps" and may at best be viewed as "desired" outcomes (cf. Pretorius 2003: 11). Compare the aims of the NLPF, which are to -

1. promote the equitable use of the 11 official languages;

2. facilitate equitable access to government services, knowledge and information;

3. ensure redress for the previously marginalised official indigenous languages;

4. initiate and sustain a vibrant discourse on multilingualism with all language communities;

5. encourage the learning of other official indigenous languages to promote national unity, and linguistic and cultural diversity; and 
6. promote good language management for efficient public service administration to meet client expectations and needs

(DAC 2003a: 13, my emphasis)

How such aims are to be measured empirically and normatively thus begs the question.

The second type of "predicted consequences" comprises "basic standards" that are "relatively specific and concretely stated objectives" (Pretorius 2003: 11). Standards are quantifiable "goods" or "services" to be "delivered" to the beneficiaries of policies within specified time frames. As far as the NLPF is concerned, its Implementation Plan states that phasing in of implementation will take place "over a reasonable period" (DAC 2003b: 7) through a range of mechanisms and structures.

In addition to existing structures such as PanSALB (including its substructures) and language offices in the national and some provincial legislatures, three new structures to support policy implementation will be established according to the NLPF:

1. Language Units in each government department and province to manage translation, editing and interpreting services with a view to the envisaged increase in the demand for these services and also for terminology development in the indigenous languages. The establishment of these units was approved by Cabinet in July 2007, four years after the publication of the NLPF. So-called key service delivery departments will be prioritised and monitored to ensure that they set up the units responsible for the translation of all their documents. These departments are Home Affairs, Justice and Constitutional Development, Social Development, Health, Safety and Security, Correctional Services, Education, Housing, Provincial and Local Government, and Land Affairs.

2. A National Language Forum (NLF), a collaborating network of representatives from government and non-government structures, to monitor the implementation process, prioritise language-related projects and drive policy advocacy campaigns under the leadership of the Department of Arts and Culture. The NLF has been (partially) functional since 2004 . 
3. The South African Language Practitioners' Council will be a statutory body established through an Act of Parliament to manage the training, accreditation, and registration of translators and interpreters to raise the status of the language profession and improve the quality of language products. This body will set and maintain standards. The Council Act has not yet been promulgated.

The NLPF's Implementation Plan envisages a broad range of mechanisms to facilitate implementation, i.e. terminology development, translation and editing, language technology, a language code of conduct, a directory of language services, language audits and surveys, language awareness campaigns, the Telephone Interpreting Service for South Africa, an information databank, the development of Sign Language, language learning, and budgeting. In terms of the above, precious few "goods" or "services" have to date been "delivered" except for a few multilingual terminology lists in addition to translation and editing services. As regards the latter, Beukes (2006: 4) points to "the underestimation and neglect of the facilitating role of translation" in post-apartheid South Africa. A 2005 survey of institutional resources for translation services in provinces and municipalities indicated that government's provision of translation infrastructure and capacity building was "seriously deficient" (Beukes 2006: 4).

In addition to existing albeit under-funded and under-staffed language offices in provinces and recently in national government departments, some 35 language structures have been created as substructures of PanSALB since its establishment in 1996. Critique on the inefficiency of these structures and the ostensible lack of delivery have pointed to significant qualitative implementation gaps (Perry 2003; Beukes 2006; Carstens 2006).

Twelve years after the publication of the Final Langtag Report and five years after Cabinet approved the long-awaited NLPF it is evident that democratic language policy and planning has not realised its "intended purposes" but has seemingly become trapped in the "gap" or "disjunction" between policy development and lack of policy implementation. 


\section{Policy as process}

Based on this rather bleak picture one is inclined to agree that expectations of realising a democratic language policy in post-apartheid South Africa have indeed been dashed. If a socalled linear model of policy processes is used according to which policy development is addressed in a sequential manner, based on "a positivist means-ends analysis" (Pretorius 2003: 17), this conclusion is inevitable. The linear model, in viewing policies as "relatively complete scripts", ignores the mutable nature of policies and their predicted outcomes and, most importantly, also "the ideological and power contests" of policy processes (Pretorius 2003: 17). However, is this not, after all, the very approach that the Langtag Report clearly discouraged when it urged government to adopt an "open-ended enabling framework" against the background of "the recent history of South Africa, the transitional character of the present period and the universal scepticism in regard to social blueprints" (DACST 1996a: 8)?

Hence I wish to argue that since the approach advocated by Langtag has perhaps fallen by the wayside over the past decade, the split between policy and implementation should be more cautiously approached in analyses of policy (Pretorius 2003). Linear models, it seems, may not be entirely suited for assessing performance in the area of language policy in South Africa because of their separation of policy development and implementation and their positivist means-ends analysis that may detract attention from the impact of "political structures and interest conflicts" (cf. Pretorius 2003). In the words of Ricento (2000: 7), "language policies can never be properly understood or analysed as free-standing documents or practices".

The time has now come to acknowledge that our policies are (relatively) incomplete and may (or perhaps should) therefore be continuously re-made following pressure and critique from interested parties. A more appropriate approach would therefore be "policy analysis beyond the policy" (cf. Pretorius 2003). In our context, Grindle and Thomas' (1990) interactive model which views policy performance and review as a dynamic process, allowing for policies to adapt and be altered, is perhaps better suited. The interactive model of policy, Grindle and Thomas (1990: 116) argue, facilitates our "(u)nderstanding the location, strength, and stakes involved in ... attempts to promote, alter, or reverse policy reform initiatives is central to understanding the outcomes" (in Pretorius 2003: 18). This is a model that makes closer dialogue possible between the domains of policy development and implementation and 
therefore politicians and bureaucrats may be held co-accountable for both policy development failure and implementation failure. Policy makers and implementers are crucial actors who may be brought to book since policy success or failure is determined by their actions.

\section{Conclusion}

The road travelled from Kempton Park's 1993 constitutional provisions via the Langtag policy process leading to Tshwane's subsequent policies (National Language Policy Framework 2003, and Implementation Plan 2003) has proven not to be the smooth ride that was envisaged at the start of the transition to a new democracy in the early 1990s. On the contrary, the road has been a bumpy and ideologically contested ride which has recently generated much debate and academic analysis. It would appear that the euphoria of "the Transition" has trapped South Africa between "intention" and "performance". The promise articulated more than two decades ago that "the African National Congress (ANC) has identified language as an area in need of planning for post-apartheid South Africa" (Eastman 1992: 95) has not borne the envisaged fruit.

The central question that this paper therefore wishes to explore is why, notwithstanding the bottom-up approaches that have characterised language policy and planning interventions in post-apartheid South Africa, disjunctions between effective policy development and implementation are still clearly evident? I wish to argue that while acknowledging the limitations of the Langtag Report, the process should not be viewed as a dead end. In congruence with the interactive model advocated by Grindle and Thomas (1990), which views policy performance and review as a dynamic process, I wish to argue that having conceded that disjunctions between policy and delivery exist, it is now time to initiate a comprehensive review of the needs and priorities identified by the Langtag process.

Blaming Tshwane for policy implementation failure should not be a substitute for pursuing comprehensive policy review and change processes. A review of policy will, among other things, have to pay close attention to "gap-producing factors" such as citizens' language preferences and repertoires and the current position and development of the African languages. 
Several important dimensions of policy require urgent and close review. Clarity must be forthcoming on the desirability of legislative measures such as the future of the long-awaited South African Languages Act and the South African Language Practitioners' Council Act. Current organisational arrangements between government's executive arm in language matters, the National Language Service, located within the national Department of Arts and Culture and South Africa's only language-dedicated statutory body, the Pan South African Language Board, must be investigated. The convoluted institutional and interest arrangements between these two pivotal language policy and planning agencies, which have given rise to a plethora of contradictory and counter-productive (power) structures, must be addressed as a matter of urgency.

The next stretch of the road will hopefully offer the opportunity to review and hence re-make South Africa's language policies to secure "a consistently democratic language policy for the simple reason that empowering the individual citizen to develop to the full extent of his or her capacity is the very point of a democratic system" (Alexander 2004: 10).

\section{Notes}

1. Adapted from Pressman and Wildavsky's (1973) "Implementation: How great expectations in Washington are dashed in Oakland".

2. Other language-related legislation includes the South African Geographical Names Council Act, 1998 (Act No. 118 of 1998), as well as section 6(1) of the South African Schools Act, 1996 (Act No. 84 of 1996) on the Minister's jurisdiction to determine norms and standards for language policy in public schools, and section 27(2) of the Higher Education Act, 1997 (Act No. 101 of 1997) on the Minister's jurisdiction to develop language policy for higher education institutions.

3. Stanfield (1994: 176) argues that "the autobiographies, cultures, and historical contexts of researchers matter; these determine what researchers see and do not see, as well as their ability to analyse data and disseminate knowledge adequately".

4. As a public servant I was a member of the Joint Conference Organising Committee for the Languages for All Conference in 1994, the co-editor of the Conference proceedings, and an ex-officio member of the Langtag Main Committee. At the request of the Main Committee I wrote a chapter of the Final Langtag Report, provided a support service to the Main Committee and its seven subcommittees for the 
duration of the entire process (1995-6), organised the Langtag Consultative Conference and edited the final version of the Langtag Report. I also managed the consultative process and public hearings on the PanSALB legislation and was a member of the technical committee that prepared the PanSALB Draft Bill (1995). In addition, I provided a support service to the Minister's Advisory Panel on Language Policy (1999-2001).

5. In the South African context this term refers to non-indigenous languages used by some communities, e.g. Dutch, German, Gujarati, Mandarin, etc.

6. Cf. Heugh (1995) for a detailed exposition of the available options at the time of the constitutional negotiations.

\section{References}

Alexander, N. 1992. Language planning from below. In R.K. Herbert (ed). Language and society in Africa. The theory and practice of sociolinguistics. Wits: Witwatersrand University Press. pp. 143-150.

Alexander, N. 2000. English unassailable but unattainable: The dilemma of language policy in South African education. PRAESA Occasional Papers 3. Cape Town: PRAESA.

Alexander, N. 2002. An ordinary country. Issues in the transition from apartheid to democracy in South Africa. Pietermaritzburg: University of Natal Press.

Alexander, N. 2004. Language policy: The litmus test of democracy in post-apartheid South Africa. Discourse 32(2): 7-11.

Beukes, A-M. 2006. Translation in South Africa: The politics of transmission. Southern African Linguistics and Applied Language Studies 24(1): 1-6.

Cape Times. 9 August 1996. Pressure media to use black languages. p. 5.

Carstens, W.A.M. 2006. Praktiese meertaligheid - Feit of fiksie? [Practical multilingualism fact or fiction?] Journal for Language Teaching 40(1): 1-19.

Constitution of the Republic of South Africa, 1993 (Act No. 200 of 1993). Pretoria: Government Printer.

Constitution of the Republic of South Africa, 1996. Pretoria: Government Printer.

DAC. 2003(a). National Language Policy Framework. 12 February 2003. Pretoria: Department of Arts and Culture.

DAC. 2003(b). Implementation Plan: National Language Policy Framework. Final Draft. 10 April 2003. Pretoria: Department of Arts and Culture. 
DACST. 1996(a). Towards a National Language Plan for South Africa. Final Report of the Language Plan Task Group (LANGTAG). Pretoria: Department of Arts, Culture, Science and Technology.

DACST. 1996(b). Issues in Language Development. Proceedings of a Langtag Workshop, 28 March 1996. Pretoria: Department of Arts, Culture, Science and Technology.

DACST. 1995. Announcing the establishment of the Language Plan Task Group (Langtag). Media statement by Dr BS Ngubane, Minister of Arts, Culture, Science and Technology, 12 December 1995.

De Klerk, F.W. 1998. The last trek - A new beginning. The autobiography. London: Macmillan.

$\mathrm{Du}$ Plessis, T. 2006. Mismatch or misfit? Critical perspectives on language policy development in South Africa. In C. Van der Walt (ed). Living through languages. An African tribute to René Dirven. Stellenbosch: SUN PReSS. pp. 37-53.

Eastman, C. 1992. Sociolinguistics in Africa. Language planning. In R.K. Herbert (ed). Language and society in Africa. The theory and practice of sociolinguistics. Johannesburg: Witwatersrand University Press. pp. 96-114.

Grindle, M. and J. Thomas. 1990. After the decision: Implementing policy reforms in developing countries. World Development 18(8): 1163-1181.

Grobbelaar, J.I. 1991. Ultra-rightwing Afrikaners: A sociological analysis. Doctoral dissertation, University of South Africa.

Herbert, 1992. Language in a divided society. In R.K. Herbert (ed). Language and society in Africa. The theory and practice of sociolinguistics. Johannesburg: Witwatersrand University Press. pp. 1-19.

Heugh, K. 1995. Disabling and enabling: Implications of language policy trends in South Africa. In R. Mesthrie (ed). Language and social History: Studies in South African sociolinguistics. Cape Town: David Philip. pp. 329-350.

Heugh, K. 2002. The case against bilingual and multilingual education in South Africa: Laying bare the myths. Perspectives in Education 20(1): 171-196.

Heugh, K. 2003. Language policy and democracy in South Africa. The prospects of equality within rights-based policy and planning. Stockholm: Stockholm University Centre for Research on Bilingualism. 
Kamwangamalu, N.M. 2000. A new policy, old language practices: Status planning for African languages in a multilingual South Africa. South African Journal of African Languages 20(1): 50-60.

Kaplan, R.B. and R.B. Baldauf, Jr. 1997. Language planning from practice to theory. Clevedon: Multilingual Matters.

Langtag. 1996. Issues in language development: Focusing on the future of the Apartheid Language Boards and the harmonisation and development of African languages. Proceedings of a Workshop presented by the Langtag Subcommittee on the Development of (South) African Languages, 28 March 1996.

Mandela, N. 1994. State of the Nation Address to Parliament, 24 May 1994. http://www.anc. org.za/ancdocs/history/mandela/1994/sp940524.html. Accessed on 14 January 2008.

Mbeki, T. 2007. Letter from the President: We are children of a rich heritage. ANC Today $7(38)$.

Moodley, K. 2000. African Renaissance and language policies in comparative perspective. Politikon 27(1): 103-115.

Moore, H. 2000. Language policies as virtual realities: Two Australian examples. In T. Ricento (ed). Ideology, politics and language policies. Focus on English. Amsterdam: John Benjamins. pp. 25-48.

Ngubane, B.S. 1996. Address at the Langtag News Conference, 8 August 1996. http://www.info.gov.za/speeches. Accessed on 19 July 2007.

Pan South African Language Board Act, 1995 (Act No. 59 of 1995). Pretoria: Government Printer.

Pennycook, A. 2000. Language, ideology and hindsight. Lessons from colonial language policies. In T. Ricento (ed). Ideology, politics and language policies. Focus on English. Amsterdam: John Benjamins. pp. 49-66.

Perry, T. 2003. Language rights, ethnic politics: A critique of the Pan South African Language Board. Praesa Occasional Paper 12. Cape Town: Praesa.

Pressman, J.L. and A.B. Wildavsky. 1973. Implementation: How great expectations in Washington are dashed in Oakland. Berkeley: University of California Press.

Pretorius, L. 2003. Six contributions to understanding 'gaps between policy and implementation': An overview and comments. Politeia 22(1): 6-21. 
Ricento, T. 2000. Ideology, politics and language policies. In T. Ricento (ed). Ideology, politics and language policies. Focus on English. Amsterdam/Philadelphia: John Benjamins. pp. 1-8.

Stanfield, J.H. 1994. Ethnic modeling in qualitative research. In N.K. Denzin and Y.S. Lincoln (eds). Handbook of qualitative research. Thousand Oaks: Sage Publications. pp. $175-188$.

Sunday Independent. 25 April 2004. We celebrate 10 years of the world's most vibrant democracy.

Sunday Times. 25 April 2004. Don't silence mother tongues. Editorial.

Verhoef, M. 1998. Funksionele meertaligheid in Suid-Afrika: 'n Onbereikbare ideaal? [Functional multilingualism in South Africa: An unattainable ideal?] Literator 19(1): $35-50$.

Webb, V.N. 2002. Language in South Africa. The role of language in national transformation, reconstruction and development. Amsterdam: John Benjamins.

Webb, V.N. 2006. The non-use of African languages in education in Africa. In C. van der Walt (ed). Living through languages. An African tribute to René Dirven. Stellenbosch: SUN PReSS. pp. 131-145. 